\title{
Partial nitritation treating nitrogen in old landfill leachate
}

\author{
Phan The Nhat, Truong Thi Thanh Van, Le Thanh Son, Ha Nhu Biec, Nguyen Phuoc \\ Dan
}

Faculty of Environment and Natural resources, Ho Chi Minh city University of Technology - Vietnam National University - Ho Chi Minh City

(Received 15 September 2016, accepted 10 November 2016)

\begin{abstract}
In this study, a lab-scale Partial Nitritation Sequencing Batch Reactor (PNSBR) was implemented for treating high-ammonium old landfill leachate to yield an appropriate $\mathrm{NO}_{2}{ }^{-} \mathrm{N} /$ $\mathrm{NH}_{4}{ }^{+}-\mathrm{N}$ ratio from $1 / 1$ to $1.32 / 1$ mixture as a pretreatment for subsequent Anammox. The objective of this study was to determine the optimal hydraulic retention time (HRT) at

210 days. The experimental results showed that with the influent ammonia concentrations of 500, 1000,1500 and $2000 \mathrm{mg} / \mathrm{L}, \mathrm{HRT}$ is $12 \mathrm{~h}$, $21 \mathrm{~h}, 30 \mathrm{~h}$ and $48 \mathrm{~h}$, respectively. The range of free ammonia (FA) concentration from 17 to 44 $m g / L$ completely inhibited nitrite oxidizing bacteria (NOB) for long time operation. The COD removal efficiency was very low $(6 \pm 2) \%$.
\end{abstract} different influent ammonia concentrations for

Keywords: Partial nitritation; old landfill leachate; AOB; SBR; NOB.

\section{INTRODUCTION}

In Vietnam, sanitary landfilling is the most common way to treat municipal solid wastes. One of the main environmental problems generated from landfill is leachate, which is containing high ammonia concentration and refractory organics [1]. The conventional nitrogen removal process requires high oxygen supplied for nitrification and external carbon source for denitrification that result in high treatment costs. In recent years, a partial nitritation coupled with anammox process was proven as a advanced technology for nitrogen removal as its low demand for oxygen and no external carbon added ([2];[3];[4]). The process involve two stages: Partial Nitritation oxidizing a part ammonium to nitrite until $\mathrm{NH}_{4}{ }^{+}-\mathrm{N} / \mathrm{NO}_{2}{ }^{-}-$ $\mathrm{N}$ ratio is about 1-1.32, ideal for the next stage anammox process (Strous et al., 1997). Application of different operational strategies for the partial nitritation has been found to enhance ammonia oxidizing bacteria (AOB) and to inhibit nitrite oxidizing bacteria (NOB) activity.

The inhibition of FA and/or free nitrous acid (FNA) to AOB and NOB is different levels. $\mathrm{AOB}$ and NOB are inhibited at higher than 10 $\mathrm{mgFA} / \mathrm{L}, 0.1-1.0 \mathrm{mgFA} / \mathrm{L}$, respectively [7]. FNA higher than $2.8 \mathrm{mg} / \mathrm{L}$ inhibits all nitrification bacteria [8]. The growth rate of $\mathrm{AOB}$ is faster than NOB that is basis of selection of the suitable HRT for partial nitritation.

However, Liang, Z. \& Liu, J. (2007) claimed that $\mathrm{pH}$, ammonia and alkalinity are not limiting factors for nitritation of landfill leachate treatment because of high strength of ammonia, alkalinity in old leachate and acclimation of AOB to FA. DO range of $0.8-2.3 \mathrm{mg} / \mathrm{L}$, the steady partial nitritation was achieved, $\mathrm{NO}_{2}^{-}-$ 
$\mathrm{N} / \mathrm{NH}_{4}{ }^{+}-\mathrm{N}$ ratio (concentration ratio) of $1.0-1.4$ in the effluent [5].

\section{MATERIALS AND METHODS}

\section{Lab-scale PN-SBR}

The reactor is shown in Figure 1. It is cylindrical tank with total height of $0.6 \mathrm{~m}$ and internal diameter of $0.42 \mathrm{~m}$, corresponding to working volume of 66.5 liters. The operating minimum volume was 26.5 liters, which is equivalent to the volume exchange ratio (VER) of $60 \%$. Air was supplied from the bottom of the reactor through air distributors, and the air flow was adjusted by using a manual valve. The feed leachate stored in 300L tank, was pumped to the reactor. Completed mixture was achieved by a mechanical stirrer at 5-10 rpm.

3

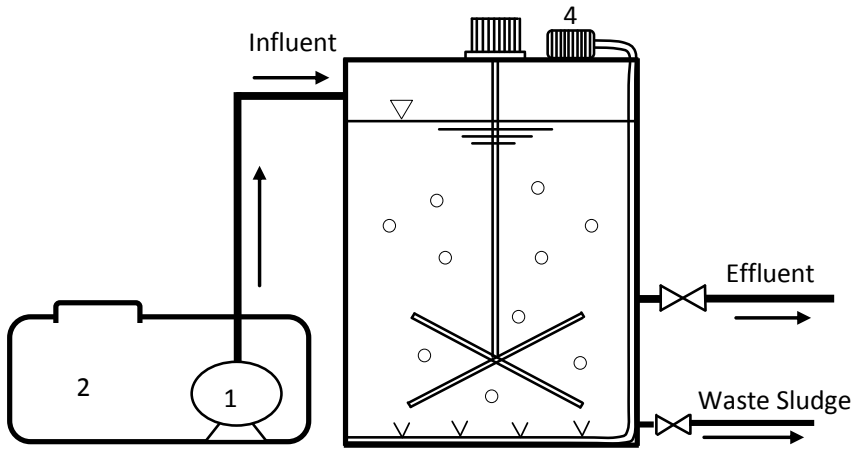

Figure 1. Schematic diagram of the lab-scale PN-SBR. (1) Metering pump; (2) feed leachate tank; (3) stirrer; (4) air pump

\section{Wastewater and sludge characteristics}

Landfill leachate used for the study was collected from Go Cat municipal solid waste landfill in Ho Chi Minh city, Vietnam. This landfill was closed 6 years ago. The characteristics of leachate were as shown in
Table. 1. The average NH4+-N concentration in landfill leachate was $3449 \mathrm{mg} / \mathrm{L}$, where an average of $\mathrm{BOD}_{5}$ was only $100 \mathrm{mg} / \mathrm{L}$, which is very low due to long time methanogenic phase [1].

Table 1. Characteristics of feed old landfill leachate

\begin{tabular}{|l|l|l|}
\hline Parameter & Unit & Mean \pm std (n=8) \\
\hline $\mathrm{pH}$ & & $8.4 \pm 0.3$ \\
\hline Alkalinity & $\mathrm{mg} \mathrm{CaCO} / / \mathrm{L}$ & $15133 \pm 58$ \\
\hline $\mathrm{TKN}$ & $\mathrm{mg} / \mathrm{L}$ & $3868 \pm 26$ \\
\hline $\mathrm{NH}_{4}{ }^{-}-\mathrm{N}$ & $\mathrm{mg} / \mathrm{L}$ & $3449 \pm 233$ \\
\hline $\mathrm{NO}_{2}{ }^{-} \mathrm{N}$ & $\mathrm{mg} / \mathrm{L}$ & $0.21 \pm 0.01$ \\
\hline $\mathrm{NO}_{3}{ }^{-}-\mathrm{N}$ & $\mathrm{mg} / \mathrm{L}$ & $2.23 \pm 0.18$ \\
\hline $\mathrm{COD}$ & $\mathrm{mg} / \mathrm{L}$ & $2761 \pm 436$ \\
\hline $\mathrm{BOD}$ & & $100 \pm 25$ \\
\hline $\mathrm{SS}$ & $\mathrm{mg} / \mathrm{L}$ & $59 \pm 16$ \\
\hline
\end{tabular}

\section{Trang 40}


The feed leachate was diluted with tap water in order to obtain the influent ammonium concentrations of 500, 1000, 1500 and 2000 $\mathrm{mg} / \mathrm{L}$.

The seed sludge was activated sludge from activated sludge tank of the Go Cat leachate treatment plant. $95 \mathrm{gVSS}$ sludge was seeded to obtain $1500 \mathrm{mgMLVSS} / \mathrm{L}$ the reactor with ratio of MLVSS to MLSS of 0.25 . This sludge was washed by tap water in order to eliminate the residue prior to the enrichment.

\section{Operating conditions}

All experiments were operated using a fedbatch mode. Each cycle included 10 minutes of feed, 45 minutes of settle and 5 minutes of decantation. The aerobic reaction time was determined by HRT, total cycle time and volume exchange ratio [9]. The HRT of the reactor was adjusted depending on the effluent $\mathrm{NO}_{2}{ }^{-} \mathrm{N}$ to $\mathrm{NH}_{4}{ }^{+}-\mathrm{N}$ ratio. According to Ganigué et al (2007), nitrogen loading rate (NLR) of PNSBR fed-batch is from 0.5 to $1.5 \mathrm{kgN} / \mathrm{m}^{3}$.d [17]. Choosing NLR of $0.5 \mathrm{kgN} / \mathrm{m}^{3} . \mathrm{d}$, this research determine HRT for enrichment phase is $21 \mathrm{~h}$. $\mathrm{pH}$ of the influent was adjusted at $7.5 \pm 0.2$ by adding $\mathrm{HCl} 20 \%$ solution into storage tank and $\mathrm{pH}$ in the reactor was not controlled. The reactor was run in the following operating conditions as presented in Table. 2

Table 2. The operating conditions of PN-SBR

\begin{tabular}{|c|c|c|c|c|c|}
\hline Phase & $\begin{array}{l}\text { Time } \\
\text { (day) }\end{array}$ & $\begin{array}{l}\mathrm{NH}_{4}^{+}-\mathrm{N} \\
(\mathrm{mg} / \mathrm{L})\end{array}$ & $\begin{array}{l}\text { HRT } \\
\text { (h) }\end{array}$ & $\begin{array}{l}\text { DO } \\
(\mathbf{m g} / \mathrm{L})\end{array}$ & Content \\
\hline 1 & $1-15$ & 500 & 21 & $1.5-2$ & $\begin{array}{l}\text { Enrichment of AOB at low DO } \\
\text { concentration. }\end{array}$ \\
\hline 2 & $16-45$ & 500 & 21 & \multirow{5}{*}{$\begin{array}{l}\text { No } \\
\text { controlled }\end{array}$} & $\begin{array}{l}\text { Enrichment of } \mathrm{AOB} \text { at high } \mathrm{DO} \\
\text { concentration. }\end{array}$ \\
\hline 3 & $46-75$ & 500 & $12,15,19$ & & \multirow{4}{*}{$\begin{array}{l}\text { To find the suitable HRTs on partial } \\
\text { nitritation performance. }\end{array}$} \\
\hline 4 & $76-110$ & 1000 & 19,21 & & \\
\hline 5 & $111-145$ & 1500 & 30 & & \\
\hline 6 & $146-210$ & 2000 & $38,41,48$ & & \\
\hline
\end{tabular}

\section{Analytical methods}

$\mathrm{pH}$ and DO were measured by using $\mathrm{pH}$ meter (HI 8314, Hanna) and DO meter (InoLab 740 with terminal 740 WTW, Germany), respectively. Total suspended solids (TSS), volatile suspended solids (VSS), $\mathrm{COD}, \mathrm{NH}_{4}{ }^{+}-\mathrm{N}$, $\mathrm{NO}_{2}{ }^{-} \mathrm{N}$ and $\mathrm{NO}_{3}^{-}-\mathrm{N}$, alkalinity were measured according to APHA (Standard Methods for examination of Water and Wastewater, 1995) (APHA, 1995). Samples were filtered using 45 $\mu \mathrm{m}$ membrane filters from Whatman, India.

\section{RESULTS AND DISCUSSION}

\section{Enrichment of AOB}

One of the studies indicated that NOB growth is more inhibited than AOB under the low DO concentration [6]. Thus, in phase 1 , the reactor was operated at DO of $1.5-2 \mathrm{mg} / \mathrm{L}$. The experimental result show that the ammonia oxidation took place slowly and the $\mathrm{NH}_{4}{ }^{+} \mathrm{-N}$ conversion efficiency was about $(17 \pm 5) \%$. The concentration of nitrite in the effluent was low and not stable $(35 \pm 33) \mathrm{mg} / \mathrm{L}$ (as shown in 
Fig.2). This demonstrates that activity AOB and NOB was both low in this phase. At the $15^{\text {th }}$ day, DO increased (phase 2). The results indicated that the conversion efficiency of $\mathrm{NH}_{4}{ }^{+}-\mathrm{N}$ to $\mathrm{NO}_{2}{ }^{-} \mathrm{N}$ gradually rose. Higher level of DO did not promote the conversion nitrite to nitrate (the average effluent nitrate concentration is $15 \mathrm{mg} / \mathrm{L}$ ). It means that the high DO concentration enhanced AOB activity while
NOB activity was still inhibited. The strong inhibition of NOB may have caused by the relatively high average FA concentration. This result was similar to the previous studies on partial nitritation ([10];[11]). On $45^{\text {th }}$ day, the enriched AOB sludge was completed, $92 \%$ of $\mathrm{NH}_{4}{ }^{+}-\mathrm{N}$ converted to $\mathrm{NO}_{2}{ }^{-} \mathrm{N}$ (as shown Figure.2), effluent nitrite concentration increased from 74 to $487 \mathrm{mg} / \mathrm{L}$ at HRT of $21 \mathrm{~h}$.

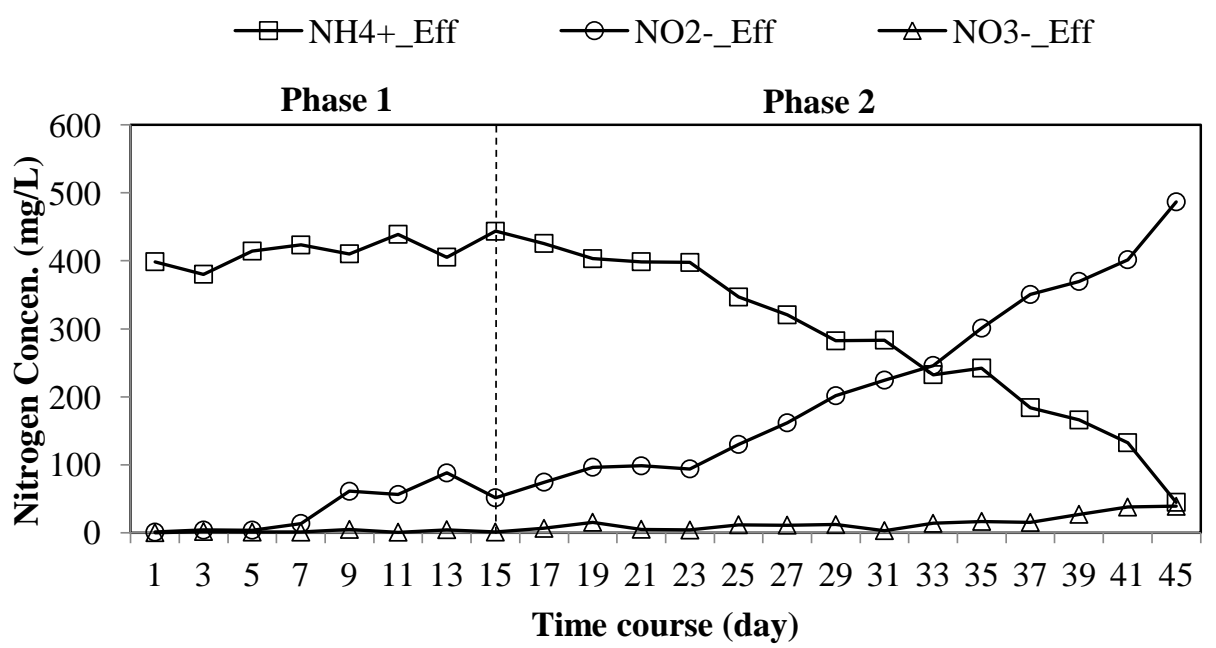

Figure 2. Time course in enrichment of AOB

\section{Performance of partial nitritation in PN-SBR}

The influent ammonia concentration of 500 $\mathrm{mg} / \mathrm{L}$

After enrichment, to determine the suitable HRT at the influent ammonia concentration of $500 \mathrm{mg} / \mathrm{L}$, PN reactor was operated at HRT of 19, 15 and $12 \mathrm{~h}$ (lower than $21 \mathrm{~h}$ ). The result show that shortened HRT lead to decrease in $\mathrm{NO}_{2}{ }^{-} \mathrm{N} / \mathrm{NH}_{4}{ }^{+}-\mathrm{N}$ ratio (as shown in Figure.3). At HRT of $19 \mathrm{~h}$, around $70 \%$ of $\mathrm{NH}_{4}^{+}-\mathrm{N}$ was oxidized to $\mathrm{NO}_{2}^{-}-\mathrm{N}$, resulting in an effluent $\mathrm{NO}_{2}{ }^{-}-\mathrm{N} / \mathrm{NH}_{4}{ }^{+}-\mathrm{N}$ ratio of 1.9 to 3.5. At HRT of
$15 \mathrm{~h}$, the effluent $\mathrm{NO}_{2}{ }^{-}-\mathrm{N} / \mathrm{NH}_{4}{ }^{+}-\mathrm{N}$ ratio decreased slowly to 1.45 . At HRT of $12 \mathrm{~h}$, this ratio was stable at the value of $1.22 \pm 0.1$ that was close to stoichiometric ratio for anammox process with the average nitrogen concentration in the effluent were $224 \pm 9 \mathrm{mgNH}_{4}{ }^{+}-\mathrm{N} / \mathrm{L}$ and $274 \pm 14 \mathrm{mgNO}_{2}{ }^{-}-\mathrm{N} / \mathrm{L}$. However, the effluent nitrate concentration of this stage was low $(15 \pm 2$ $\mathrm{mg} / \mathrm{L}$ ), equivalent to $3 \%$ of the influent ammonia concentration. 


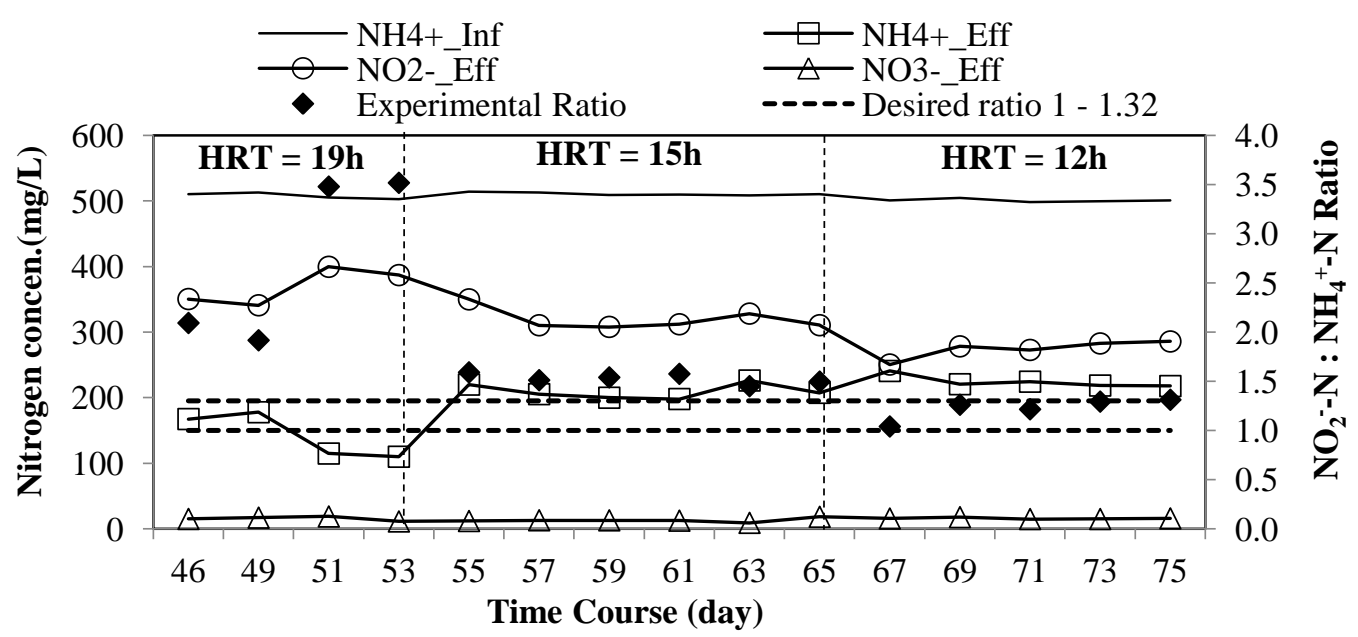

Figure 3. Nitrogen transformation in the PN-SBR at the influent ammonia concentration of $500 \mathrm{mg} / \mathrm{L}$

The influent ammonia concentration of 1000 $m g / L$

The results are illustrated in Figure. 4. During the first 10 days, the study was operated at HRT of $19 \mathrm{~h}$. The average effluent $\mathrm{NO}_{2}^{-}$ $\mathrm{N} / \mathrm{NH}_{4}{ }^{+}-\mathrm{N}$ ratio was about 0.67 . It can be explain by shock of bacteria when the influent concentration rose remarkably. When HRT increased up to $21 \mathrm{~h}, \mathrm{NO}_{2}{ }^{-}-\mathrm{N} / \mathrm{NH}_{4}{ }^{+}-\mathrm{N}$ ratio achieved to 1.41 after 10 operational days with the average effluent ammonia and nitrite concentration of $473,534 \mathrm{mg} / \mathrm{L}$, respectively. In next days, the removal ammonia efficiency was suddenly decreased to $47 \%$, resulting to decreasing of $\mathrm{NO}_{2}{ }^{-}-\mathrm{N} / \mathrm{NH}_{4}{ }^{+}-\mathrm{N}$ ratio $(0.75)$. The reason was failure of $\mathrm{pH}$ meter that could not adjust the expected $\mathrm{pH}(7.5 \pm 0.2)$. The influent $\mathrm{pH}$ at this point was higher than 7.80 , which effected negatively on AOB. However, recovery of the system was quickly afterward. Nitrate formation was insignificant. 


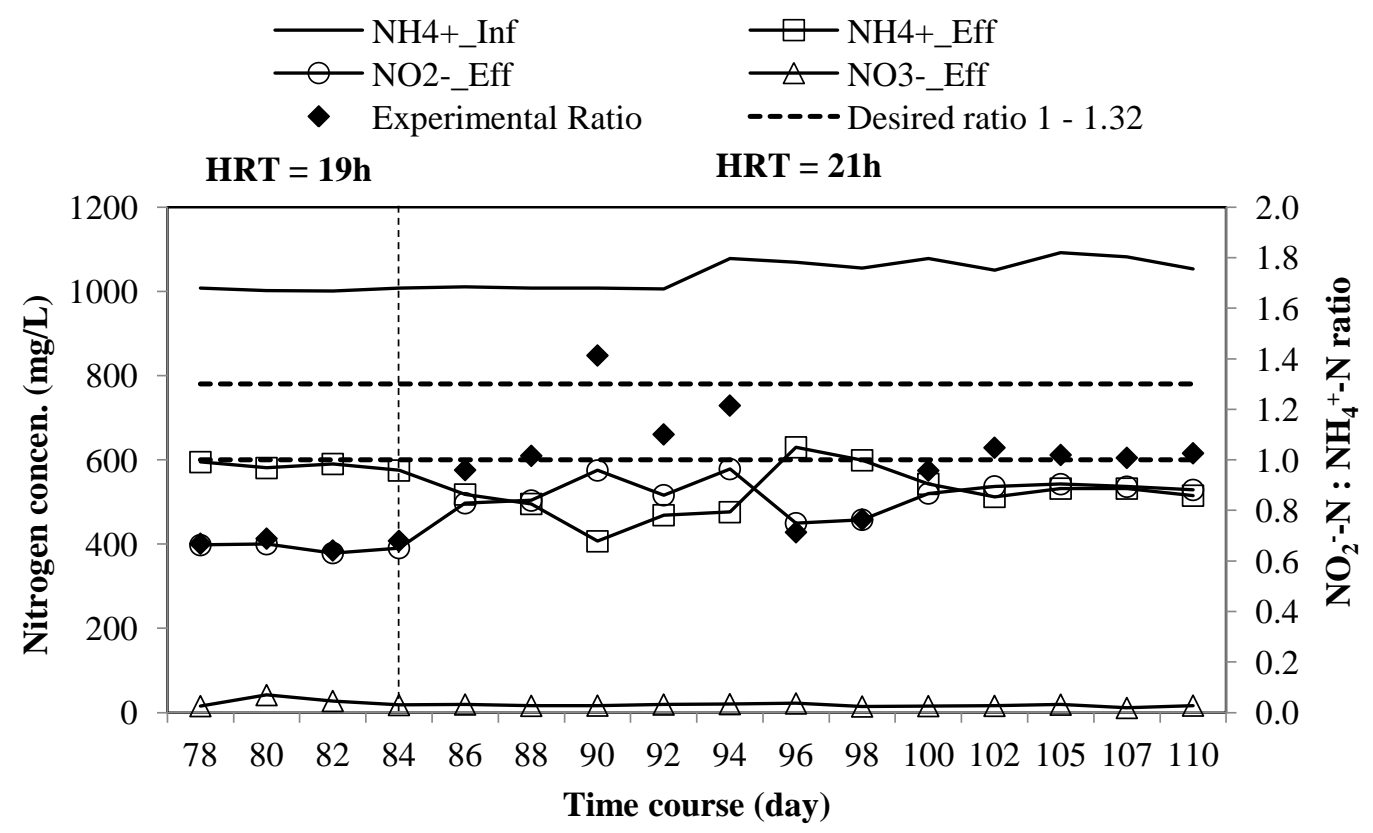

Figure 4. Time course of nitrogen transformation in the PN-SBR at the influent ammonia concentration of $1000 \mathrm{mg} / \mathrm{L}$

The influent ammonia concentration of 1500 $m g / L$

In this phase, the reactor was run at HRT of $30 \mathrm{~h}$. From $111^{\text {st }}$ to $120^{\text {th }}$ day, the conversion of ammonia to nitrite was low because AOB was not adapted to increased ammonia concentration. The ammonia conversion efficiency during these days was about $14-48 \%$, effluent $\mathrm{NO}_{2}{ }^{-} \mathrm{N} / \mathrm{NH}_{4}{ }^{+}-\mathrm{N}$ ratio was $(0.72 \pm 0.2)$. After $120^{\text {th }}$ day, AOB was gradually adapted to high ammonia concentration. The conversion of $\mathrm{NH}_{4}{ }^{+}-\mathrm{N}$ to $\mathrm{NO}_{2}{ }^{-}-\mathrm{N}$ was more than $55 \%$ equivalent to $\mathrm{NO}_{2}{ }^{-}-\mathrm{N} / \mathrm{NH}_{4}{ }^{+}-\mathrm{N}$ effluent ratio of $(1.05 \pm 0.15)$. The production of nitrate was account for $2 \%$ the influent ammonia concentration. 


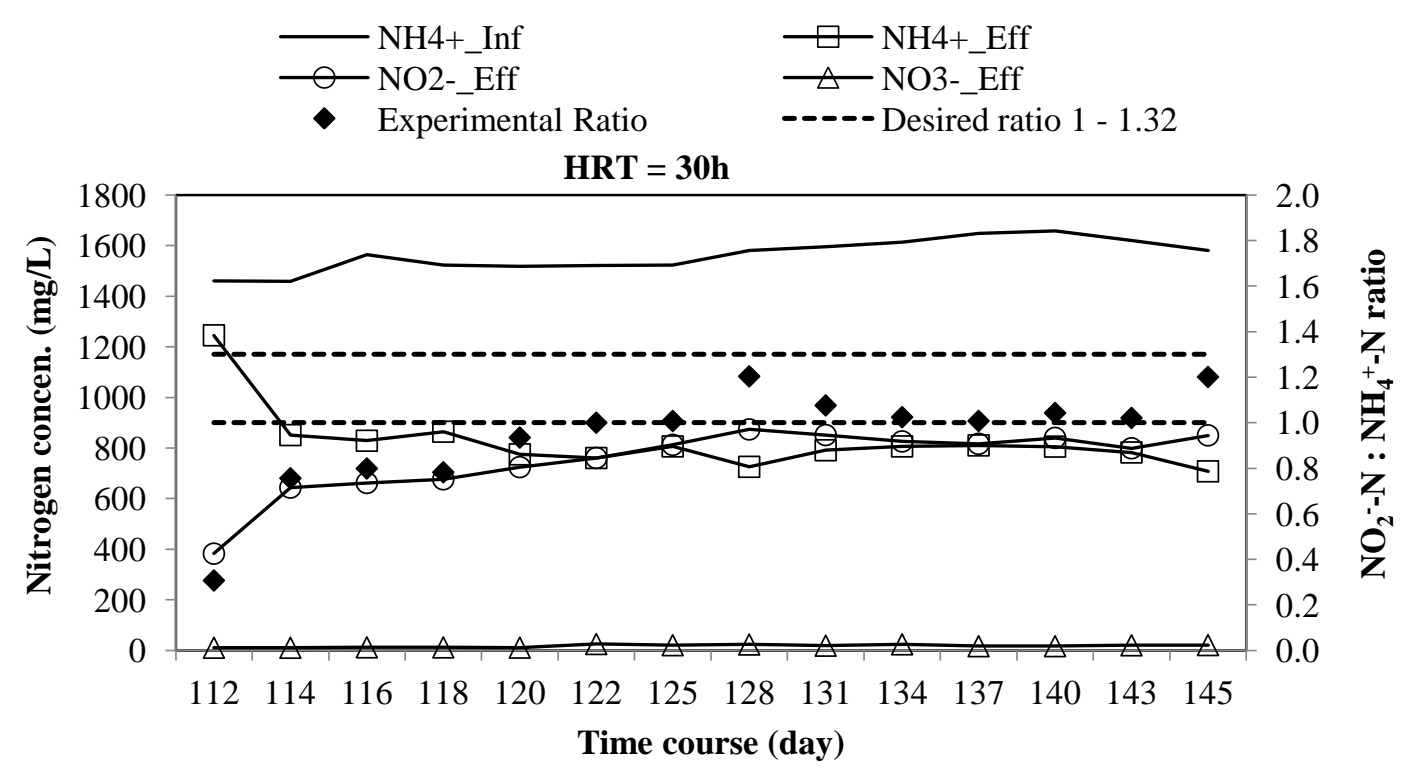

Figure 5. Time course of nitrogen transformation in the PN-SBR at the influent ammonia concentration of $1500 \mathrm{mg} / \mathrm{L}$

The influent ammonia concentration of 2000 $\mathrm{mg} / \mathrm{L}$

Figure. 6 illustrates that the conversion of ammonia to nitrite gradually increase when HRT was extended. Efficiency of conversion ammonia to nitrite is very low $(30 \pm 2) \%$ with the effluent $\mathrm{NO}_{2}{ }^{-} \mathrm{N} / \mathrm{NH}_{4}{ }^{+}-\mathrm{N}$ ratio of $(0.3 \pm 0.04)$ at HRT of $38 \mathrm{~h}$ for 30 days. When HRT was raised to $41 \mathrm{~h}$, partial nitritation did not achieve yet. HRT continued to rise to $48 \mathrm{~h}$. Partial nitritation was achieved. The effluent $\mathrm{NH}_{4}{ }^{+}-$
$\mathrm{N} / \mathrm{NO}_{2}{ }^{-}-\mathrm{N}$ ratio was about 1 and the average effluent ammonia and nitrite concentration was $1006 \mathrm{mg} / \mathrm{L}, 1004 \mathrm{mg} / \mathrm{L}$. The effluent nitrate concentration is still low $(20 \pm 1) \mathrm{mg} / \mathrm{L}$. The results showed that the increase of HRT up to $48 \mathrm{~h}$ did not cause noteworthy formation of nitrate. However, findings of Hellinga et al [12] and Akio Ota et al [11] showed that HRT $48 \mathrm{~h}$ existed accumulation of NOB. 


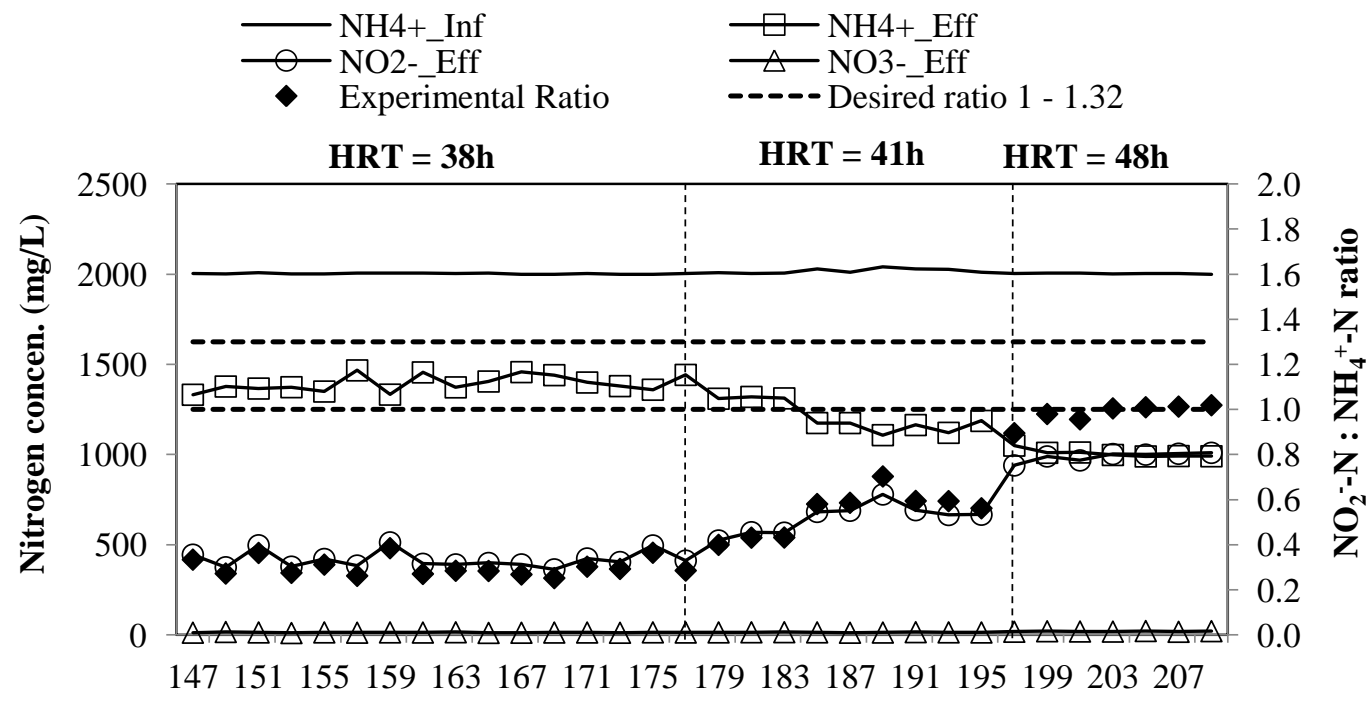

Time course (day)

Figure 6. Time course of nitrogen transformation in the PN-SBR at the influent ammonia concentration of 2000 $\mathrm{mg} / \mathrm{L}$

In the end days of each phase, when partial nitritation was achieved, the result shows that FA concentration was the range of (17-44 $\mathrm{mg} / \mathrm{L})$. According to Anthonisen et al., FA higher than $10 \mathrm{mg} / \mathrm{L}$ inhibited AOB [7]. It indicated that the AOB population used in this experiment adapted to high FA concentrations.

The average conversion ammonia rate in this study was about $20 \pm 1.34 \mathrm{mgNH}_{4}{ }^{+}$$\mathrm{N} / \mathrm{gVSS}$.h.This value is lower than the previous studies of Mosquera-Corral et al [13] (150 $\mathrm{mgNH}_{4}{ }^{+}$-N/gVSS.h); Jianwei Chen et al [14] (124 $\mathrm{mgNH}_{4}{ }^{+}-\mathrm{N} / \mathrm{gVSS} . \mathrm{h}$ ) and Wang and Yang [15] (115 $\mathrm{mgNH}_{4}{ }^{+}$-N/gVSS.h) for synthetic wastewater. For landfill leachate, this value is higher than that of study of Spagni et al [16] (12.6 $\mathrm{mgNH}_{4}{ }^{+}$-N/gVSS.h). Thus, AOB activity in this study was rather high.

\section{COD removal}

COD removals of PN are shown in Figure. 7. The influent COD of leachate ranges from 567 to $2189 \mathrm{mg} / \mathrm{L}$. Fig. 7 shows that the COD removal efficiency was low $(6 \pm 2) \%$, due to the low ratio of $\mathrm{BOD}_{5} / \mathrm{COD}$ about 0.1 . Ganigué et al [17] presented, the leachate had $\mathrm{BOD}_{5} / \mathrm{COD}$ ratio of 0.15 , COD removal ranged from 11 to $14 \%$. It shows that the organic matter of this old leachate is mainly refractory. So, influence of COD concentration on partial nitritation did not exist in this study. 


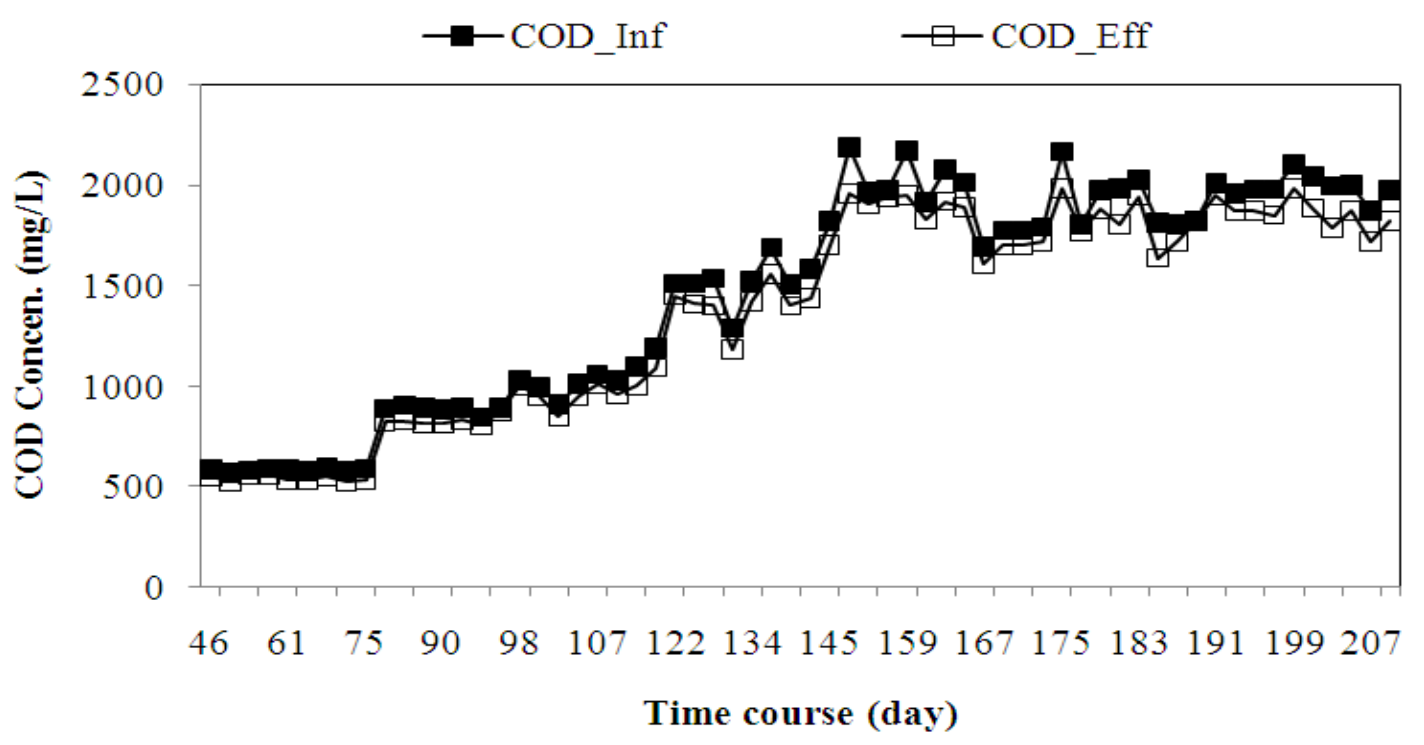

Figure 7. Time course of COD removal

\section{CONCLUSIONS}

Partial nitritation achieved low nitrate concentration and the ratio of $\mathrm{NO}_{2}-\mathrm{N} / \mathrm{NH}_{4}{ }^{+} \mathrm{N}$ from $1 / 1$ to $1.32 / 1$ which is suitable for anammox process at the influent ammonia concentration of $500 \mathrm{mg} / \mathrm{L}$ with HRT of $12 \mathrm{~h}$, of $1000 \mathrm{mg} / \mathrm{L}$ with HRT of $21 \mathrm{~h}$, of $1500 \mathrm{mg} / \mathrm{L}$ with HRT of $30 \mathrm{~h}$, of $2000 \mathrm{mg} / \mathrm{L}$ with HRT of $48 \mathrm{~h}$.

Although DO is not controlled and considered high compare to other similar researches, NOB was inhibited for old landfill leachate.
Organic removal was not significant due to low $\mathrm{BOD}_{5} / \mathrm{COD}$ ratio of old landfill leachate.

In this study, the old landfill leachate was diluted. Therefore, further studies need to increase the influent concentration of ammonia or nitrogen loading rate to evaluate the nitrogen removing ability of the PN-SBR model. 


\title{
Quá trình nitrit hóa bán phần xử lý nitơ trong nước rỉ rác cũ
}

\author{
Phan Thế Nhật, Trương Thị Thanh Vân, Lê Thanh Sơn, Hà Như Biếc, Nguyễn Phước \\ Dân
}

Khoa Môi trường và Tài nguyên thiên nhiên, trường Đại học Bách khoa, Đại học Quốc gia Thành phố Hồ Chí Minh

\section{TÓM TẮT}

Trong nghiên cưu này, mô hình thí nghiệm Nitrit hóa bán phần dạng mẻ (Partial Nitritation Sequencing Batch Reactor - PNSBR) đước dùng xủ lý nước rỉ rác cũ với ammonium cao để đạt được tỷ lẹ $\mathrm{NO}_{2}{ }^{-} \mathrm{N} / \mathrm{NH}_{4}{ }^{+}-\mathrm{N}$ tù̀ $1 / 1$ đến 1.32/1 nhu là quá trình tiền xủ lý cho Anammox. Mục tiêu của nghiên cứu này nhà̀m xác định thời gian lưu nước tối ưu ở nhũ̃ng nồng độ ammonia đầu vào khác nhau trong 210 ngày. Kết quả thí nghiệm

Tù khoá: nitrit hoá bán phần; Nước rỉ rác cũ; $A O B$; SBR; $N O B$.

\section{REFERENCES}

[1]. Kjeldsen P, Barlaz M A, Rooker A P, "Present and long-term composition of MSW landfill leachate: A review", Critical Reviews in Environmental Science and Technology, Vol. 32(4), pp.297-336, 2002.

[2]. van de Graaf A A, de Bruijn P, Robertson L A et al.,"Autotrophic growth of anaerobic ammonia-oxidizing microorganisms in a fluidized bed reactor", Microbiology, Vol.142, pp. 2187-2196, 1996.

[3]. Turk O, Mavinic D S, "Maintaining nitrite build-up in a system acclimated to free ammonia", Wat Res, Vol. 23, pp.13831388, 1989.

[4]. Khin T, Annachhatre A P, "Novel microbial nitrogen removal processes", Biotechnology Advances, Vol.22, pp.519532, 2004. cho thấy rằng với nồng độ amonia đầu vào là 500, 1000, 1500 và $2000 \mathrm{mg} / \mathrm{L}$ thì thòi gian lưu nước lần lượt là $12 \mathrm{~h}, 21 \mathrm{~h}, 30 \mathrm{~h}$ and $48 \mathrm{~h}$.Nồng độ amonia tụ do trong thí nghiệm tù 17 đến 44 $m g / L$ úc chế hoạt động của vi khuẩn nitrat hóa trong suốt thời gian vận hành. Hiệu quả loại bỏ COD được ghi nhận trong quá trình thí nghiệm là rất thấp $(6 \pm 2) \%$.
[5]. Liang, Z. \& Liu, J., "Control factors of partial nitritation for landfill leachate treatment", J. Environ. Sci, Vol.19, pp. 523 $-529,2007$.

[6]. Ruiz G, Jeison D, Chamy R, "Nitrification with high nitrite accumulation for the treatment of wastewater with high ammonia concentration", Wat Res, Vol.37, pp.1371-1377, 2003.

[7]. Anthonisen A C, Loehr R C, Prakasam T S et al.,"Inhibition of nitrification by ammonia and nitrous acid", J. Water Pollut Control Fed, Vol.48, pp.835-852, 1976.

[8]. van Hulle, S.W.H., Volcke, E.I.P., Teruel, J.L., Donckels, B., van Loosdrecht, M.C.M., Vanrolleghem, P.A., 'Influence of temperature and $\mathrm{pH}$ on the kinetics of the Sharon nitritation process", J. Chem. Technol. Biotechnoly, Vol.82, pp.471-480, 2007. 
[9]. Hoang Viet Yen. Optimization of partial nitrification and denitrification processes in landfill treatment using sequencing batch reactor technique. Thesis (PhD), University of Liege, France, 2009.

[10].Wang Jianlong and Yang Ning, "Partial nitrification under limited dissolved oxygen conditions", Process Biochemistry, Vol.39, pp.1223-1229, 2003.

[11].Akio Ota, Ayako Yoshida and Tohru Nakahira, "Control method for restoration from nitrate accumulation to nitritation", Frist International Anammox Symposium, Vol.1, pp. 39-44, 2011.

[12].Hellinga, C., Schellen, A.A.J.C., Mulder, J.W., Van Lossdrecht, M.C.M., Heijnen, J.J., "The Sharon process: an innovative method for nitrogen removal from ammonium-rich wastewater", Water Sci. Technol, Vol.34, pp.135-142, 1998.

[13].Mosquera-Corral, A., Gonzalez, F., Campos, J.L., Mendez, R., "Partial nitrification in a SHARON reactor in the presence of salts and organic carbon compounds", Process Biochemistry, Vol.40, pp.3109-3118, 2005.

[14].Jianwei Chen, Ping Zheng, Yi Yua, Qaisar Mahmood, Chongjian Tang., "Enrichment of high activity nitrifers to enhance partial nitrification process", Bioresource Technology, Vol.101, pp.7293-7298, 2010.

[15].Wang, J.L., Yang, N., "Partial nitrification under limited dissolved oxygen conditions", Process Biochemistry, Vol. 39, pp.1223-1229, 2004.

[16].Alessandro Spagni, Stefano MarsiliLibelli., "Nitrogen removal via nitrite in a sequencing batch reactor treating sanitary landfill leachate", Bioresource Technology, Vol.100, pp.609-614, 2009.

[17].Ganigué, R., López, H., Balaguer, M.D., Colprim, J.,"Partial ammonia oxidation to nitrite of high ammonia content urban landfill leachates", Water Res, Vol.41, pp.3317-3326, 2007 